\title{
Pierre Bayle: Religion Ecology Through the Eyes of a Skeptic
}

\author{
Marina Doguzhieva \\ Bauman Moscow State Technical University \\ 5/1, 2nd Baumanskaya St. \\ Moscow, Russia 105005 \\ E-mail: aniramd@list.ru
}

\begin{abstract}
The article considers a complex of ideas of Pierre Bayle, the famous French thinker of the XVIIth century, related to the religion, morality, and freedom. The great Voltaire, who, like all enlighteners, experienced the strongest influence of Bayle's main work "The Historical and Critical Dictionary", not without reason asserted: "Bayle has everything, you have only to be able to find." The author believes that in the present conditions of the activation of religious institutions the actuality of Bayle's humanistic skepticism will increase.
\end{abstract}

Keywords-skepticism; religion; toleration; freedom of conscience; morality; atheism

\section{INTRODUCTION}

The modern stage of human development is characterized by a widespread exacerbation of problems related to religion, both ideological, and institutional $[1,2]$. As yet secular - in full accordance with the Constitution of the Russian Federation - the educational system in our country allows students to form their own position on this matter, introducing them to the historical experience of free-thinking. Unfortunately, this is mainly not Russian, but European experience. However, in view of the fact that Russia is primarily the European civilization heir, the history of nonreligious and non-clerical European thought formation can be very instructive for the younger generation. In this regard, Pierre Bayle (1647-1706), the "second echelon" French philosopher, who is not usually included in the New European philosophers' brilliant assemblage, however, is the figure of great interest. This scientist managed not to be lost in the XVIIth century rich in great minds but, on the contrary, left a very significant mark in the history of European Enlightment.

\section{PIERRE BAYLE LIFE AND DESTINY}

Pierre Bayle was born in the south of France - in Languedoc, where the Jewish and Arab traditions were historically strong. The Southern France had always been characterized by non-orthodoxy (it is enough to recall the Cathars, Albigensian and other heretical movements that took place here in the Middle Ages). However, Bayle's father was a Protestant pastor (Huguenot, or rather, a Calvinist), and this fact was supposed to ensure strict religious upbringing. But, there was a huge library in the house, the religion problems were discussed with the educated family friends, and the father, noticing his son outstanding abilities and excellent memory, tried to give him the best education. Excessive and unsystematic reading even brought the young Bayle to illness! After studying at the Protestant seminary, he was sent to study philosophy in the University of Toulouse where Jesuits taught. Under his teachers influence (the members of this famous Catholic Order had a rare gift of persuasion) Bayle was converted to Catholicism for a whole year! He even tried to convert to Catholicism his elder brother, who had already served as pastor, but, of course, he did not find understanding in the family. As a result, having found no special moral and dogmatic advantages in the Catholic faith, Bayle was converted to Protestantism again. We should mention that, although religious wars between Catholics and Huguenots had ended about a century before (thanks to the Edict of Nantes on religious toleration of King Henry IV), the memory about it was still fresh, and selfidentification on religious grounds retained its defining significance [3].

Among the philosophers who influenced Bayle in the most powerful way, we must primarily name the "skeptical humanist" M. Montaigne (1533-1592), whose philosophy Bayle was addicted to (while still a teenager), and the great $\mathrm{R}$. Descartes (1596-1650), whose "doubt" as the Cartesian metaphysics initial principle proved to be particularly significant for Bayle. The XVIIth century discoveries in natural sciences also played their part, and sometimes met faithful clerics' fierce resistance. Again, it is worth recalling that, although the horrors of the Counter-Reformation that had been gone by then, a heavy struggle for the science independence from the ideological church censure continued [4]. Bayle completed his education at the University of Geneva - one of the most advanced for his time, where great attention was paid to the natural sciences. Next, he worked for a while as a home teacher, lived in Rouen and in Paris. Finally, in 1675, Bayle, thanks to one of his university friends, became a professor of philosophy at the famous Protestant Academy in Sedan. A popular teacher, he showed himself as a fighter against superstitions and prejudices: when once before an official court a nobleman was accused of having connections with the devil, Bayle published an anonymous pamphlet, where thanks to his wit and brilliance 
the accusers "arguments" were blown out of the water [3]. However, the Protestant Academy of Sedan greatly annoyed the Catholic King Louis XIV - and, despite the promise to support the Protestant education given to high-ranking Protestants, he closed it in 1681. Bayle, having lost his job, was invited to ÉcoleIllustre in Rotterdam to the department of philosophy: in a Huguenots persecutions new round, Bayle was one of the many French Protestants forced to immigrate to Holland. The future showed anopportuneness of this step - in fact, in 1685 Louis XIV abolished the Edict of Nantes on religious toleration, andProtestants persecution in France increased. Bayle's elder brother, Jacob, who refused to renounce his faith, died in prison; his father's ashes were taken from his grave and scolded. Deeply grieving about this, Pierre wrote a book about the political situation in Catholic France: however, he defended not his coreligionists Protestants, but the very religious tolerance principle - it was so typical for him!

In Holland until 1693, Bayle worked as a professor of history and philosophy at Rotterdam University. Besides teaching, he wrote a lot of books, won the fame among scientists and deserved though dangerous (under the conditions offierce religious strife) reputation as an indefatigable fighter for free-thinking and religious tolerance, including in relation to atheists. The French authorities banned Bayle's books, and one of them was even publicly burned (which, however, only contributed to his writings popularity). Such people as a writer and scholar B. Fontenelle (1657-1757), E. Shaftesbury, philosopher, writer and politician (1671-1713), an English aristocrat (who believed that the best weapon against fanaticism was to ridicule it), the great G. Leibniz (1646-1716) and the other intellectual elite representatives of that time were among his friends and correspondents.

Using the press freedom, by which Holland differed from all European countries, Bayle published some books banned in France (including several works on Descartes). Being an encyclopedic educated person, he contributed to the scientific knowledge popularization, having published in 1684 the philosophical and scientific journal "News from the Republic of Letters". In this edition, which was published only for three years (and banned in his homeland France), Bayle established the intellectual honesty highest standards and open, benevolent disputes on the newest ideas and theories in various fields of knowledge, impartial evaluation of any argumentspro et contra. In the midst of frenzied enmity and fanatic intolerance, Bayle defended the freedom of thought and conscientious constructive criticism, imbued with respect for opponents. It is worth noting that even in modern conditions, such a level of discussion sometimes seems unattainable ... The obscurantists from both the Catholic and Protestant sides unleashed a real persecution of the philosopher. Gradually, even in relatively tolerant Holland, Bayle's views began to seem too radical. He was accused of religious indifference and almost atheism for his courageous defense of religious tolerance. Finally, Bayle's journal was closed, and its independent editor lost the university professor position in 1693. He was banned from even private teaching! However, these changes had positive consequence; it was the opportunity to tackle a long-planned dream - publishing his final work Historical and Critical Dictionary (1695-1697) (Dictionnairehistorique etcritique) on the cover of this work Bayle first put his own name (all previous books were printed anonymously). In this famous work, in disguised form he set out the views destructive to the universally recognized values and prejudices of his time. Dictionary has sustained nine editions over 50 years (not counting two in English) and played a significant role in the European free thought development. It became a brilliant great Encyclopedia of the XVIIIth century prototype - the intellectual and spiritual foundation of the Enlightenment.

Although under strict censorship Bayle was extremely cautious in presenting his critical ideas (hiding them behind an ingenious form, with frequent references to extensive notes and various articles, etc.), Dictionary made a strong impression on the reading public. The Dictionary neutral academic form, chosen by the philosopher, did not deceive the religious dogmatists, who found in the text (and especially in numerous notes to it) many "blasphemies" against the Christian religion. For example, the ruthless characteristic of Christianity in times of the CounterReformation revelry (the XVIth century): "... it was a bloody religion, carrying death, accustomed to the massacre for five or six centuries. This religion distorted the norms of behavior and action developed over a long period, destroying everything that resisted it with weapons" [5].

Both Orthodox Catholics and Protestant fanatics cursed Bayle again and declared him the enemy of Protestant church as well as the enemy of his new homeland - Holland. These hostile attacks greatly spoilt the philosopher's life; at that time he also had seriously fallen ill. Considering the disease fatal, Bayle, despite his friends' advice, refused to take medicines. He treated his physical suffering and the imminent death with all the calm, without reducing his work intensity up to the last day of his life. Bayle died in Rotterdam on December 28, 1706.

\section{BAYLE ABOUt RELIGION AND MORALITY}

Bayle's doctrine was essentially a line of skepticism continuation (from antiquity to Bayle's predecessor Montaigne). Bayle's skeptical free thought involved him in the religious, political and scientific struggle of the XVIIth century. It may seem that Bayle's mission was only to criticize and to destroy: after all, as a true skeptic, he did not create his own positive system of views. However, the significance of his theoretical work cannot be overestimated.

Devoting his live to the fight against Christian fanatics, who justified cruelty and brutality against other religious confessions representatives, Bayle came up to the idea that all confessions are equivalent and equal and called for the respect for various religious beliefs. Due to his religious indifference, he evoked Catholics and Huguenots equal hatred. Having managed to rise above the religious dogmatic quarrels of his era, Bayle sent all his skepticism to the very possibility of the rationality of the religious dogmas, denying the theology validity and even the possibility of any evidence of the existence of God. Not only the theological idea about 
Universe, but also the religious interpretation of morality became Bayle's criticism object: he managed to debunk the fundamental - the dependence of morality on religion. We should note that a century before Bayle, an Italian thinker of the late Renaissance Pietro Pomponazzi had also attempted to make a non-religious morality rationale, and the philosopher's ideas had a great influence on the European free-thought development [6].

Bayle refuted the thesis that religion makes people moral, and atheism - immoral, by many examples of atrocities committed by Christian believers, and the impeccable moral life of many "godless" sages. He proclaimed that the human morality basis is the "natural conscience light" given to people directly, intuitively. Deeply interpreting Descartes, who wrote about the "natural reason light" axioms, Bayle asserted that each person has the ability to distinguish between bad and good, vice and virtue. Although sometimes he recognized that in every human conscience voice there is the voice of God Himself, Bayle actually freed the human conscience from the connection with religion and Holy Scripture. Moreover, he sharply condemned Christian fanaticism for violence against the conscience of people forced to take the alien faith.

Of course, Bayle understood that personal individual features (character, mentality, etc.) and the social environment impact can muffle the voice of conscience, but he denied a direct link between the person's moral character and his faith in God considering that a person might be vicious or virtuous, and it does not depend on the fact that he knows or does not know about the all-seeing God, but it is because of the inborn temperament peculiarities and the education he has received [7]. Spinoza also wrote that the human motives for actions were rather in the emotions and interests fields than in people religious beliefs but he did not draw such far-reaching conclusions from this assumption as Pierre Bayle did.

\section{BAYLE ABOUT ATHEISM AND MORALITY}

The Bayle's idea about the absence of a logical connection between religiosity and morality anticipated a violent and contradictory formation of enlightening atheism. His acute questions: "What is the greater evil - atheism or false religion?" and "Can atheists be moral people?" became the center of debate in the XVIIIth century. Bayle argued that, in an ethical sense, an atheist could be not only not lower, but also much higher than a believer could. This approach was very bold for XVIIth century because the idea of possible existence of a quite successful and morally stable society composed of atheists seemed incredible even in a far more free-thinking Franceof XVIIIth century. Montesquieu (who called the idea "a Bayle paradox") and Voltaire shared a common opinion that an atheistic society would inevitably destroy because of mass immorality (in the absence of "spiritual clasps» of religiously sanctified ethics). However, many French enlighteners of the XVIIth century took this Bayle's idea (and it was partly verified by subsequent historical practice ...). Although Bayle did not consider himself an atheist, the great Voltaire said about him: "If Bayle himself is not an unbeliever, he makes others become unbelievers." From his ideas Bayle did not draw radical anticlerical conclusions (like the need to separate church and state and turn religion into a private matter for believers) but these conclusions were inevitably made by his followers.

\section{BAYLE'S SKEPTICISM}

Bayle extended his skepticism from religion to traditional philosophy, criticizing the rationalism for the assertion that metaphysics axiomatic statements are reliable. Denying the metaphysics credibility, defended by Descartes, Spinoza and Leibniz (who was in correspondence with Bayle), he considered that a complete philosophical system was impossible in principle (for this reason he did not attempt to create his own one) $[8,9]$. Disclosing the contradictions in the speculative constructions of the great rationalists of the Modern Age, Bayle came to the disappointing conclusion that even these philosophers can "present only a more or less happy game of their imagination" and that no metaphysical system can claim absolute truth. Perhaps this belief was the reason why Bayle chose a dictionary form for his final work, rather than writing a theoretical treatise, where the simple alphabetical examination of diverse material contrasted with the pseudo-systematic character of metaphysics.

At the same time, Bayle himself remained a rationalist who considered the mind to be the "supreme tribunal" and the "last echelon" in solving all issues. He did not doubt the laws of logic and the truths of mathematics (as well as intuitive beliefs of moral consciousness!) As M. Kuznetsov the author of the article on Bayle in the modern philosophical Encyclopedia - rightly points out: Bayle's skepticism "is constructive, creative in nature" appears as "a critical reflection aimed at finding the truth"[10].

\section{CONCLUSION}

Evaluating Bayle's philosophical work, such a radical thinker as Karl Marx (1818-1883) noted that he carried out a "negative refutation of theology and metaphysics of the XVIIth century" [11]. Bayle's skepticism was brilliantly continued in the works of the XVIIIth century Enlightenment philosophers: Bayle's impartial logic and elegant wit inspired Montesquieu and Voltaire, as well as Rousseau, Diderot and other encyclopedists. Such famous philosophers as D. Hume and L. Feuerbach experienced Bayle's tangible influence [12]. Closer to our time, one cannot fail to see a certain similarity (both in content and in ideas presentation in a dictionary form) of Bayle's philosophy with postmodernist approaches. However, Bayle may be of interest to the younger generation, educated in the XXIth century, not only as an example of a subtle intellectual game. Undoubtedly,the main achievement of the French philosopher-skeptic is his struggle - in theory and in practice - for freedom of conscience and freedom of mind, against the persecution of people for their beliefs, and this struggle is relevant at all times. 


\section{REFERENCES}

[1] Suzdaleva T.R. Migratory processes in the context of geopolitics // VestnikTomskogogosudarstvennogouniversiteta-Filosofiyasotsiologiya-politologiya-Tomsk state university journal of philosophy sociology and political science. 2016. № 3 (36). P. 237244. DOI: $10.17223 / 1998863 \mathrm{X} / 35 / 25$

[2] Gubanov N.I., Gubanov N.N. The role of mentality in the development of society: sociocultural hypothesis // Vestnikslavianskikhkultur-bulletin of slavic cultures-scientific and informational journal. 2017. Vol. 43. № 1. P. 38-51.

[3] Nesterenko A.N. Bishop Albert // Voprosyistorii. 2015. № 3. P. 50-68.

[4] Komissarov I; Nekhamkin V. The Models of Historical Cognition: Current Status and Prospects of Development // IstoriyaElektronnyinauchno-obrazovatelnyuzhurnal. 2017. Vol. 8. Issue 2. DOI: 10.18254/S0001779-5-1

[5] Beyle, Pierre. Historical and critical vocabulary, in two volumes, vol.2, Moscow, Mysl Publ.,1968.

[6] Pomponazzi, Pietro. Treatises on the Immortality of the Soul, on the Causes of Natural Phenomena, or on Witchcraft, Moscow, Publishing House AON Publ., 1990.

[7] Gubanov N.I., Gubanov N.N.Mentality: the nature and functioning in society // Voprosyfilosofii. 2013. № 2. P. 22-32.

[8] IvlevV.Yu.,Ivleva M.L. Peculiarities of Aristotelian scholastic logic // "Proceedings of the 2017 2nd International Conference on Contemporary Education, Social Sciences and Humanities". (ICCESSH 2017).Part of the series ASSEHR. Moscow, Russia.P.9195.

[9] IvlevV.Yu., Lepskaya N.D.Modalities and logic // "Proceedings of the 2017 2nd International Conference on Contemporary Education, Social Sciences and Humanities". (ICCESSH 2017).Part of the series ASSEHR. Moscow, Russia. V.124. P.79-86.

[10] New Philosophical Encyclopedia. In four volumes, vol. 1, Institute of Philosophy of the Russian Academy of Sciences Publ., Moscow, Mysl Publ., 2010, p. 230.

[11] Marx, K., Engels, F. The Holy Family or Criticism of Critical Criticism - Collected Works, ed. 2, vol. 1, Moscow, Publishing House of Political Literature Publ., 1955, p. 142.

[12] Feuerbach, Ludwig. Pierre Beyle. To the history of philosophy and humanity. In book: History of Philosophy, vol.3 (3), Moscow, Mysl Publ., 1967. 